\section{Gas Chromatography Symposium}

THE second symposium on "Gas Chromatography" will take place at the Tropical Institute, Amsterdam, during May 19-23, 1958. The meeting is being organized by the Gas Chromatography Discussion Group under the auspices of the Hydrocarbon Research Group of the Institute of Petroleum, and the Koninklijke Nederlandse Chemische Vereniging. It is intended that the programme shall be divided into three sections: $A$, theoretical ; $B$, apparatus and techniques; $C$, applications. The official language at the symposium will be English. Original contributions and a 250 word abstract (two copies) should be submitted to the Secretary before Novem. ber 20. Those papers describing applications of the techniques should have some novel feature. Application for registration must reach the Secretary before March 1, the fee being approximately 45 guilders, which will include the cost of preprints and receptions. Further information can be obtained from the Secretary, G. Dijkstra, Unilever Research Laboratory, Veersingel, Vlaardingen, Netherlands.

\section{Bedson Club}

THE thirty-first annual general meeting of the Bedson Club, King's College, Newcastle on Tyne, was held on October 18. The programme of Bedson Lectures during 1957-58 will be: November 1, Dr. Dorothy Crowfoot Hodgkin, "The Structure of Vitamin $\mathrm{B}_{12}$ "; November 22, Prof. A. J. Birch, "Recent Studies in Relation to Biosynthesis"; January 31, Dr. J. W. Linnett, "The Structure of Flames"; March 7, Dr. H. Seligman, "Use of Radioactive Materials in Industry".

\section{The Night Sky in November}

FULL moon occurs on November 7d. 14h. 32m. U.T., and new moon on November 21d. $16 \mathrm{~h} .19 \mathrm{~m}$. The following conjunctions with the Moon take place: November 19d. 03h., Jupiter $3^{\circ} \mathrm{N}$. ; November $25 \mathrm{~d}$. $14 \mathrm{~h}$., Venus $8^{\circ} \mathrm{S}$. In addition to these conjunetions with the Moon, Mercury is in conjunction with Antares on November 17d. 13h., Mereury being $2 \cdot 7^{\circ} \mathrm{N}$., Jupiter with Spica on November 21d. 17h., Jupiter being $3.4^{\circ} \mathrm{N}$, , and Mercury with Saturn on November 21d. 21h., Mercury being $3 \cdot 6^{\circ} \mathrm{S}$. There will be a total eclipse of the Moon on November 7, invisible at Greenwich. Mereury is too close to the Sun for observation. Venus sets at $18 \mathrm{~h} .20 \mathrm{~m}$., $18 \mathrm{~h}$. $35 \mathrm{~m}$. and $18 \mathrm{~h}$. $55 \mathrm{~m}$. at the beginning, middle and end of the month, respectively; during this time its distance from the Earth decreases from 75 to 53 million miles, the visible portion of the apparent disk from 0.578 to 0.428 , and its stellar magnitude from -3.9 to $-4 \cdot 2$. It is a brilliant object in the south-west after sunset; greatest eastern elongation is on November 18 . Mars rises at about $5 \mathrm{~h} .40 \mathrm{~m}$. throughout the month; it is visible in the south-east just before sunrise. Jupiter rises at $4 \mathrm{~h} .55 \mathrm{~m} ., 4 \mathrm{~h} .20 \mathrm{~m}$. and $3 \mathrm{~h} .35 \mathrm{~m}$. at the beginning, middle and end of the month, respectively ; it is near Spica. The stellar magnitude of Jupiter is $-1 \cdot 3$, its distance from the Earth on November 15 being 585 million miles. Saturn appears too close to the Sun for observation. Occultations of stars brighter than magnitude 6 are as follows, observations being made at Greenwich : November 9d. 19h. 13.9m., 97 Tau. $(R)$; November 14d. 0h. $24 \cdot 7 \mathrm{~m}$., $\mathrm{A}^{2}$ Cnc. $(R) ; R$ refers to reappearance. The Taurid meteors are active during Novem. ber 1-10 and the Leonids during November 15-17, but conditions are not favourable for observation.

\section{Announcements}

Dr. A. D. Merriman, who has been registrar. secretary of the Institution of Metallurgists for the past ten years, is to retire at the end of this year. He will be succeeded on January 1, 1958, by Mr. R. G. S. Ludlam, who has been assistant registrar in the University of Leeds since 1951.

THe Faraday Society Bourke Lectures will be given by Prof. W. Jost, of the University of Göttingen. The lectures are: "Reactions in Detonations and Shock Waves", to be given in the Lecture Theatre of the Department of Physical Chemistry, University of Cambridge, Free School Lane, on October 28, at 4.30 p.m. (chairman, Prof. R. G. W. Norrish); "Flame Reactions", to be given in the Lecture Theatre, Inorganic Chemistry Laboratory, South Parks Road, Oxford, on Oetober 31, at 5 p.m. (chairman, Mr. R. P. Bell); and "Crystal Defects, especially near Phase Transitions", to be given in the Main Lecture Theatre, Chemistry Department, the Imperial College of Science and Technology, London, on November 4, at 5 p.m. (chairman, Sir Eric Rideal).

THE autumn meeting of the British Society for Immunology will be held at the Wellcome Foundation, 183 Euston Road, London, during November 15-16. The first day will be devoted to a symposium on "Immuno-hæmatology" from 10 a.m. (chairman, Prof. J. V. Dacie).

The Institute of Physies (London and Home Counties Branch) has organized a Symposium on "The Design of Physics Research Laboratories" to be held at 2.30 p.m. on November 27 in the Lecture Theatre of the Royal Institution, 21 Albemarle Street, London, W.1. Admission is by ticket, obtainable from the Institute of Physics, 47 Belgrave Square, London, S.W.1, to which all inquiries should be made.

THE Institute of Biology is arranging a second international symposium on "Freezing and Drying", which will be held in the Beveridge Hall, Senate House, London, W.C.1, on April 1 and 2, 1958. Further information can be obtained from the Secretary, Institute of Biology, 41 Queen's Gate, London, S.W.7.

THe Eighth Canadian High Polymer Forum will be held at MacDonald College, Quebec, Canada, during May 12-14, 1958. The meeting is sponsored by the National Research Council of Canada and the Chemical Institute of Canada and will cover all aspects of polymer science. Further information can be obtained from Dr. L. A. McLeod, Research and Development Division, Polymer Corporation, Ltd., Sarnia, Ontario, Canada.

AT the annual general meeting of the British Society of Rheology, held at the University College of Swansea on September 19, the following elections were made for the year 1957-58: President, Prof. E. G. Richardson; Hon. Secretary, Mr. N. Wookey; Hon. Treasurer, Mr. D. W. Jopling; Hon. Editors, Dr. E. W. J. Mardles and Dr. J. C. Vernon; New Members of the Committee, Dr. M. F. Culpin, Dr. A. Jobling and Mr. G. H. Tattersall. Information concerning the Society can be obtained from the Hon. Secretary, 52 Tavistock Road, Edgware, Middlesex. 